\title{
VILÁGUNK MEGISMERÉSE ÉS MŰKÖDÉSÉNEK MEGÉRTÉSE LEGALÁBB OLYAN FONTOS, MINT AZ INNOVÁCIÓ
}

\section{GETTING TO KNOW OUR ENVIRONMENT AND UNDERSTANDING HOW IT WORKS IS AS IMPORTANT AS INNOVATION}

\author{
Páll-Gergely Barna', Dékány Éva ${ }^{2}$, Toldi Gergely ${ }^{3}$, Schlosser Gitta ${ }^{4}$, Török Péter ${ }^{5}$ \\ ${ }^{1}$ PhD, MTA Agrártudományi Kutatóközpont Növényvédelmi Intézet, Budapest \\ pall-gergely.barna@agrar.mta.hu \\ 2PhD, MTA Nyelvtudományi Intézet \\ ${ }^{3} \mathrm{PhD}$, Semmelweis Egyetem Laboratóriumi Medicina Intézet \\ 4PhD, Eötvös Loránd Tudományegyetem Természettudományi Kar Analitikai Kémiai Tanszék \\ ${ }^{5}$ DSc, MTA-DE Lendület Funkcionális és Restaurációs Ökológiai Kutatócsoport, Debreceni Egyetem Természettudományi Kar \\ Ökológiai Tanszék
}

\begin{abstract}
ÖSSZEFOGLALÁS
Az elmúlt hónapokban nagy médiafigyelmet kapott az innováció, valamint a tudományos alapkutatás társadalmi hasznosságának kérdése. A hazai kutatók gyakran hangsúlyozzák, hogy az alapkutatás elválaszthatatlan az alkalmazott kutatástól, elengedhetetlen előfeltétele annak. Írásunkban arra szeretnénk rámutatni, hogy az alapkutatást nemcsak az alkalmazott kutatás szemszögéből kellene megítélni, hiszen célja nem csupán a jövőbeni innovációk elősegítése, hanem környezetünk megismerése és ismereteink előzetes, korlátozó koncepcióktól mentes bővítése.
\end{abstract}

\section{ABSTRACT}

Issues regarding innovation and the usefulness of basic research for society have received increased media attention in the last couple of months. Hungarian researchers often have emphasized that basic research is not separable from applied research; the former is the indispensable prerequisite for the latter. In our article we hope to point out that basic research should not only be judged by its relevance to applied research. The aim of basic research is not only to advance future innovation, but to get to know our environment, and extend our knowledge without coercive conceptions.

Kulcsszavak: alkalmazott kutatás, alapkutatás, innováció, társadalmi hasznosság

Keywords: applied research, basic research, innovation, usefulness 
A tudományos kutatást - némileg mesterséges módon - szokás két részre különíteni: felfedező (más néven alap-), illetve alkalmazott kutatásra. Az utóbbi konkrét gazdasági problémákra keresi a megoldást, mely pénzben kifejezhető hasznot hoz, az elöbbi ilyen értelemben vett gazdasági hasznossága, mondjuk úgy, egyelöre nem látható. A két eltérő típusú kutatás szembeállítása folyamatos konfliktusokat szül, annak ellenére is, hogy gyakran az alapkutatás, az alkalmazott kutatás és a hozzá kapcsolódó innováció kéz a kézben jár, egymástól nem választhatók el. Az alkalmazott kutatás és innováció létjogosultságát természetesen nem kell magyarázni. Hatékonyabb motor kifejlesztése, olcsóbb vegyületszintézis-utak kikísérletezése, ellenállóbb fémötvözetek fejlesztése belátható gazdasági (értsd: pénzügyi) haszonnal jár. Ezzel szemben felmerül a kérdés, hogy „,miért fordítjuk az adófizetők pénzét olyasmire, aminek nincs haszna”. „Nem szabadna olyan tudósokat képezni, akik például a bogarak életét kutatják.” Nem jó az a rendszer, amiben „,mindenki azt kutat, amit akar"... ismerjük ezeket a gyakran visszatérő gondolatokat.

Ha Heinrich Hertz nem fedezte volna fel a rádióhullámokat, ma nem lenne többek között mobiltelefon. Ha Alexander Fleming nem fedezte volna fel a penicillint, most nem tudnánk gyógyítani a bakteriális fertőzéseket, és biztosan nem így alakultak volna a 20. század demográfiai viszonyai. Albert Einstein relativitáselmélete nélkül ma bajosan tudnánk GPS-t használni. Ha a Curie házaspár nem a radioaktivitás kutatásának szenteli az életét, most nem lennének atomerőműveink. Álljunk itt meg egy pillanatra! Vajon a radioaktivitás felfedezése csak az atomerömüvek miatt ,érte meg”, vagy azért is, mert így megtudhattuk a kőzetek korát és a dinoszauruszok kipusztulásának időpontját? Utóbbi - jelenlegi ismereteink szerint - nem feltétlenül „,hasznos”, csupán ,érdekes”, és legalábbis a mi véleményünk szerint fontos is.

Ha az élővilág oldaláról közelítjük meg az alapkutatás problémakörét, akkor azt mondhatjuk, hogy jelenleg kb. 1,2 millió eukarióta élőlényt (állat, növény, gomba stb.) ismerünk, és a legutóbbi becslés szerint még nagyjából további 8,7 millió (!) vár felfedezésre. Ez azt jelenti, hogy a Földet benépesítő fajok majdnem 90\%-a ismeretlen a tudomány számára. Hogy lehet ezt beépíteni az alapkutatás-alkalmazott kutatás tengelybe? Természetesen kreatívok vagyunk e téren: (i) Azért kell például ormányosbogarakat kutatni, mert sokuk mezőgazdasági kártevő, és az azonosításuk rendkívül fontos az ellenük való védekezésben. (ii) Azért kell kérészeket kutatni, mert a vízminősítésben jelentős a szerepük. (iii) Azért kell méheket és lepkéket kutatni, mert ők porozzák be a virágokat, melyekből gyümölcsök lesznek. (iv) Azért kell a növények természetes elterjedését kutatni, mert így gyorsan felismerjük egy-egy idegenhonos faj felbukkanását, mely akár magas egészségügyi kockázatot is magában hordozhat (például parlagfü)... és a sort még sokáig folytathatnánk.

Alapvető kérdés azonban, hogy vajon tényleg azért kellene a minket körülvevő természetes sokféleséggel és törvényszerüségekkel foglalkozni, mert valamikor 
majd az így nyert eredmények fizikailag jobbá tehetik az életünket? Tényleg ennyire „technokrata” módon kellene hozzáállni ehhez a kérdéshez? Természetesen nem azt kívánjuk sugallni, hogy a fenti érvek valótlanok, inkább azt, hogy fordítva ülünk a lovon, ha a felfedező kutatást kizárólag a gazdasági hasznosság irányából közelítjük meg. Az ismert fajok túlnyomó része nem használható élőhely-minősítésre, nem kártevő, vagy nem hajt hasznot, azaz jelenlegi korlátozott ismereteink szerint „mindegy”, hogy ismerjük öket, vagy nem. Az alapkutatás célja és értéke azonban nem korlátozódik az alkalmazott kutatás kiszolgálására, még akkor sem, ha a közbeszéd ezt próbálja elhitetni velünk az utóbbi időben. Nyilvánvalóan minden tudományágnak részét képezik olyan kutatások, melyek előbb-utóbb hasznosulnak, és olyanok is, amelyek nem. A sokak által hangoztatott ,,praktikus” gondolatmenetből azonban egy fontos dolog hiányzik, ez pedig a körülöttünk lévő világ megismerése és megértése iránti jogos és indokolt emberi igény. József Attila költészetének tanulmányozása, a honfoglaló magyarok életének megismerése, az ismeretlen fajok leírása nem azért fontos, mert gazdasági haszna van, pénz valószínüleg nem lesz belőle. A nemzeti múltunk, müvészetünk és világunk jelenségeinek megismerését nem gazdasági szempontból kell megítélni.

A 19. század közepéig-végéig a felfedezéseket jellemzően a gazdag, felvilágosult magánszemélyek adományai katalizálták, illetve számos jómódú ember hobbiként ủzte a tudományt. Az expedíciós hajók föleg nemesfémek és füszerek után kutattak, de odafelé befért egy-egy természetbúvár, a visszatérő rakományba pedig pár kitömött madár, lepréselt növény, törzsfönöki fejdísz és néhány szép lepke is. Manapság a tudomány erre nagyon korlátozott mértékben számíthat. Lássuk be, ma már ritkán látunk tehetős üzletembereket, akik szabadidejükben lepkéket gyüjtenek, vagy a Hold krátereit vizsgálják. Másrészt be kell látnunk, hogy a tudomány megváltozott. A rohamosan bővülő ismeretek további kiterjesztéséhez már nem elegendő a tudomány magányos hobbiként való úzése. Az előrehaladás teljes állású, elkötelezett kutatókat kíván, akiknek egyre gyakrabban kell megküzdeniük komplex problémák megoldásával, ennek érdekében pedig sokszor csoportokba kell tömörülniük, és együtt kell dolgozniuk. A fenti okok miatt a mai alapkutatóknak az állam által szétosztott adóforintokért kell versengeniük. A modern pályázati rendszert lehet kritizálni, hiszen iparszerü és termelésalapú lett. Nem támogatja például az elmélyült, hosszú távú kutatást a rövid időléptékben számolt, nagymértékben megnövekedett publikációs kényszer miatt. Mégis, a tudományon belüli kiválóság, a nemzetközi szinten jegyzett kutatások díjazása egy olyan rendszert teremtett világszerte, mely hatékonyan képes segíteni környezetünk megismerését.

A kutatás költséges tevékenység, bár minden relatív. A hazai rendszer még a nemzetközi szinten mérsékeltnek mondható támogatással is kiemelkedően teljesít. A megszerzett tudás gazdaságilag vagy hasznosul, vagy nem. Ezt el kell fogadnunk, ez a tudomány természete. Ha a tudás ily módon nem hasznosul, ak- 
kor sem „haszontalan”, az emberiség szellemi örökségének részét fogja képezni. Nekünk, kutatóknak ezt jobban kell hangsúlyoznunk. A felfedező kutatást meg kéne szabadítani az innováció és a gazdasági hasznosság értelmetlen és állandó kényszerétől, és úgy kellene rá tekinteni, amire elsődlegesen való: a tudásunk gyarapításának eszközére. A társadalom jogos igénye az, hogy a kutatóknak hozzá kell járulniuk az életminőség javításához az adóforintokért cserébe. Ez viszont nemcsak a rákgyógyítást és a müholdas tévét jelenti, hanem - legalábbis előremutatóan gondolkodó, nemzetközi szinten intellektuálisan versenyképesnek maradni kívánó társadalomban - azt is, hogy tudjuk, milyen a klíma a Marson, hol a magyar helye a többi nyelv között, milyen madár énekel a kertünkben, és hogy müködik egy hangyakolónia. 